\title{
NEURO-FUZZY MODELING: A PROMISING ALTERNATIVE FOR RISK ANALYSIS IN URBAN AFFORESTATION MANAGEMENT ${ }^{1}$
}

\author{
Adriano Bressane ${ }^{2 *}$, João Augusto Bagatini ${ }^{3}$, Carlos Humberto Biagolini ${ }^{4}$, José Arnaldo Frutuoso \\ Roveda $^{5}$, Sandra Regina Monteiro Masalskiene Roveda ${ }^{5}$, Felipe Hashimoto Fengler ${ }^{2}$ and Regina Márcia \\ Longo $^{6}$

\footnotetext{
${ }^{1}$ Received on 04.11.2016 accepted for publication on 12.12.2017.

${ }^{2}$ Universidade Estadual Paulista, Departamento de Engenharia Ambiental, São José dos Campos, SP - Brasil. E-mail: $<$ adrianobressane@ymail.com> and < adriano.bressane@ict.unesp.br>.

${ }^{3}$ Prefeitura Municipal de Nova Prata, Nova Prata, RS - Brasil. E-mail: <florestal@novaprata.gov.br>.

${ }^{4}$ Universidade Estadual Paulista, Campus de Sorocaba, Sorocaba, São Paulo - Brasil. E-mail: <carloshbiagolini@ig.com.br>. ${ }^{5}$ Universidade Estadual Paulista, Departamento de Engenharia Ambiental, Sorocaba, SP-Brasil. E-mail: < roveda@sorocaba.unesp.br $>$ and <sandra@sorocaba.unesp.br>.

${ }^{6}$ Universidade Católica de Campinas, Faculdade de Engenharia Ambiental, Campinas, SP-Brasil. E-mail: $<$ felipe_fengler@hotmail.com>. *Corresponding author.
}

\begin{abstract}
Urban afforestation has important functions, but problems related to its management are equally relevant, analysis of which is needed in order to prevent accidents. However, due to the subjectivity in the assessment, there may be uncertainty as to the seriousness of the risk. In order to address this, the present work evaluates a neuro-fuzzy-based methodology for the integrated analysis of risk indicators. From the knowledge of experts and a database with 107 cases, systems were constructed for the multi-criteria analysis of 18 parameters integrated using 3 indexes and 5 indicators. As a result, the model presented accuracies of $95.5 \%$ in generalization tests, and almost perfect agreement (kappa $>0.8)$ with the assessment by the expert. In conclusion, the findings show that this neuro-fuzzy modeling approach represents a promising alternative for supporting risk analysis in urban afforestation.
\end{abstract}

Keywords: Risk indicators; Integrated analysis; Uncertainties.

\section{MODELAGEM NEURO-FUZZY: UMA ALTERNATIVA PROMISSORA PARA ANÁLISE DE RISCOS NO MANEJO DA ARBORIZAÇÃO URBANA}

RESUMO - A arborização urbana tem funções importantes, mas os problemas relacionados à sua gestão são igualmente relevantes, cuja análise é necessária para prevenir acidentes. No entanto, devido à subjetividade inerente a avaliação, pode haver incertezas quanto à gravidade do risco. Como alternativa, o presente trabalho avalia uma proposta metodológica baseada em modelagem neuro-fuzzy para análise integrada de indicadores de risco. A partir da consulta a especialistas e de um banco de dados com 107 casos, foram construídos sistemas para análise multicritério de 18 parâmetros, integrados por meio de 3 índices e 5 indicadores. Como resultado, o modelo apresentou acurácia de 95,5\% nos testes de generalização, e concordância quase perfeita (kappa > 0,8) com a avaliação pelo especialista. Em conclusão, os resultados mostram que a modelagem neuro-fuzzy representa uma alternativa promissora para apoiar a análise de risco na arborização urbana.

Palavras-Chave: Indicadores de risco; Análise integrada; Incertezas. 


\section{INTRODUCTION}

Urban afforestation contributes to better air quality, soil conservation, retention of water pollutants, and creation of ecological corridors, as well as positive visual, acoustic, and climatic effects (Galenieks, 2017; Morelli et al., 2012). Wooded areas provide scenic beauty and a sense of well-being, with spaces for leisure and socializing (Bryant, 2006; Baumgarten, 2006; Godbey et al., 2005).

Despite the importance of afforestation for quality of life, inadequate planning and management can create risks to the population and result in material losses or even fatalities. Due to the lack of planning, species of inappropriate size are often planted, which can lead to damage to buildings, road systems, and public lighting (Santos and Teixeira, 2001). Some of the consequences of lack of appropriate management include the development of diseases associated with chancre, fungi, and parasitic plants, with occurrence of lesions, fractures, and necrosis. As a consequence of the compromised vitality, tree falls can occur and cause material damage, affecting humans, other trees, and animals (Martins et al., 2010; Volpe-Filik et al., 2007). Several studies can be found that highlight the severity and frequency of this problem, with observation of large proportions of compromised trees (Sampaio et al., 2010; Gonçalves et al., 2007; Volpe-Filik et al., 2007).

For the above reasons, risk analysis of afforestation is essential to support measures for the preventive management of accidents. However, since many of the criteria employed are based on the perception of risk by experts, the assessment involves uncertainties due to the associated subjectivity (Gonçalves et al., 2007). Therefore, the use of a model based on fuzzy logic for integrated analysis of the indicators may be a useful approach that has already shown promising results in studies involving uncertainties (Bressane et. al., 2017; Janssen et al., 2010). To this end, the present study presents a methodology based on neuro-fuzzy modeling to support the integrated analysis of risk indicators in the management of urban afforestation, with evaluation of the technique using a case study.

\section{MATERIALS AND METHODS}

\subsection{Data collection for modeling and the case study}

The neuro-fuzzy based modeling was evaluated by applying it in a case study. The data collection was performed in the grounds of a social club located in the city of Lajeado (Rio Grande do Sul State), partially occupied by urban afforestation, resulting in the database for the present work. At the site, evaluation was made of trees that could pose a risk due to their proximity to built-up areas and movement of people, totaling 107 individual trees belonging to 38 species. Many of these trees were from native vegetation that had occupied the area before installation of the buildings, the road system, and the leisure infrastructure of the club. Of the trees evaluated, 80 belonged to species native to the region.

The collection was carried out considering risk indicators associated with phytosanitary and environmental conditions. The evaluation of phytosanitary status included the occurrence of diseases associated with the presence of chancre, fungus, gall, and parasitic plant, as well as structural damage related to senility, lesions, fractures, cavities, necrosis, epicormic branches, and included bark. The environmental conditions were evaluated based on factors associated with the site, such as impermeable compacted soil, reduced soil volume resulting in exposed roots, and parameters related to climate, topography, interference with the environment, and potential targets such as people and material assets. The procedures and materials were based on the visual tree assessment (VTA) method developed by Mattheck and Breloer (1994, 1997). A rubber hammer was used for percussion in order to identify sound differences between healthy and injured regions. A sufficiently long rod (screwdriver) was used to measure injuries such as fractures and cavities, and a penetrating object (pocketknife) was used to assess the mechanical resistance of the tissues. The occurrence of the risk indicators was then recorded using a form containing a checklist, with spaces for observations made based on the VTA. From these procedures, each tree individual was classified by the expert according to the following scale: risk absent (1), minimum risk (2), moderate risk (3), worrying risk (4), and very worrying risk (5). Thus, the attribution of the risk class by the expert resulted from an analysis based on the individual's perception, knowledge, and experience. Therefore, given the subjectivities inherent in this qualitative evaluation, it was proposed that the use of fuzzy modeling could contribute to achieving an integrated analysis of the indicators.

Revista Árvore. 2018;42(1):e420106

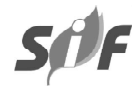




\subsection{Modeling based on fuzzy systems and hierarchical analysis}

The proposed model consisted of fuzzy and neurofuzzy systems constructed from priorities defined by the analytic hierarchy process (AHP) method. The first step consisted of selecting variables following an expert consultation. Thus, disease indicators $\left(I_{1}\right)$ and structural integrity indicators $\left(I_{2}\right)$ were selected for modeling a risk index associated with phytosanitary status $\left(R_{\mathrm{p}}\right)$. In turn, indicators concerning the soil $\left(I_{3}\right)$ and external factors related to climate, topography, and surroundings $\left(I_{4}\right)$ were selected for modeling a risk index associated with environmental condition $\left(R_{\mathrm{E}}\right)$. In addition, indicators of potential targets were selected $\left(I_{5}\right)$. The integrated analysis of $I_{5}, R_{\mathrm{P}}$, and $R_{\mathrm{E}}$ resulted in a global risk index $\left(R_{\mathrm{G}}\right)$.

Weighting was performed using an importance scale of the variables, as proposed by Thomas L. Saaty, the developer of the hierarchical analysis method, with values ranging from 1 (equivalent importance) to 9 (extreme importance) (Saaty, 2008). By using this scale, a comparison matrix is generated $(\boldsymbol{A})$. From that, the importance of the variables is expressed as a vector $(w)$, associated with the maximum eigenvalue $\left(\lambda_{\max }\right)$, obtained using:

$$
\operatorname{det}\left(A-\lambda_{\max } I\right)=0
$$

After determining $\lambda_{\max }, w$ is calculated as the eigenvector that solves the equation:

$$
\lambda_{\max } w=A w .
$$

The prioritization process is then validated when the consistency ratio $\left(R_{\mathrm{C}}\right)$ is less than or equal to 0.1 :

$$
R_{c}=C_{I} / R_{i},(3)
$$

where $\mathrm{R}_{i}$ is a tabulated value according to the dimension of the matrix, and $C_{I}$ is the consistency index, given by:

$$
C_{I}=\left(\lambda_{\max }-n\right) /(n-1) .
$$

From the prioritization of the variables, three fuzzy systems were constructed. The first two systems $\left(S_{1}\right.$ and $S_{2}$ ) were modeled by the Mamdani method (Mamdani and Assilian, 1975), and the third one $\left(S_{3}\right)$ was constructed as a neuro-fuzzy system (Jang, 1993).

In the modeling process, the variables were fuzzified using trapezoidal and triangular functions (Eq. 5) in systems $S_{1}$ and $S_{2}$, as well as by gaussian functions in $S_{3}$ (Eq. 6):

$$
\begin{aligned}
& \varphi_{F}(x)=\max \left(\min \left(\frac{x-a}{b-a}, 1, \frac{c-x}{c-b^{\prime}}\right), 0\right)(5) \\
& \varphi_{F}(x)=\exp \left(-\frac{(x-\bar{x})^{2}}{2 \sigma^{2}}\right),(6)
\end{aligned}
$$

where $\varphi_{F}(x)$ is the membership of the input $x$ in the fuzzy set $F$, and $a, b, b^{\prime}$, and $c$ are the parameters that delimit the regions of certainty and uncertainty. For triangular functions, the parameters $b$ and $b$ 'are equal. The average and standard deviation are indicated by $\bar{x}$ and $\sigma$, respectively.

In the next step, a rule base relating the input and output variables was constructed using conditional statements of the type:

$$
\text { IF } x \text { is } A \text { THEN } Z \text { is } B \text {. }
$$

In the systems based on the Mamdani method $\left(S_{1}\right.$ and $\left.S_{2}\right)$, the aggregation was carried out with use of the minimum operator $(\mathrm{t}$-norm $\Lambda)$ in the antecedents, and the maximum operator (s-norm $\mathrm{V}$ ) in the consequents. Thus, the systems with a total of $r$ rules were constructed as a max-min composition $(R)$, given by:

$$
R(x, y)=\max _{1 \leq i \leq r}\left(\varphi_{A i}(x) \wedge \varphi_{B i}(y)\right) .
$$

The defuzzification was performed by the centroid method (Eq. 9), and the output values were standardized to reach the boundaries of the original domain (Eq. 10):

$$
\begin{aligned}
& Y=\sum_{i=1}^{k} \varphi_{i} Y_{i} / \sum_{i=1}^{k} \varphi_{i},(9) \\
& Y=Y_{e s t}\left(Y-Y_{\text {min }}\right) /\left(Y_{\text {max }}-Y_{\text {min }}\right),(10)
\end{aligned}
$$

where $Y$ is the defuzzified value, $Y_{\text {est }}$ is the highest value in the variable domain, and $Y_{\min }$ and $Y_{\max }$ are the minimum and maximum values achievable in the inference process, respectively.

In $S_{3}$, the rule base and the parameterization of the functions were modeled by means of an adaptive neuro-fuzzy inference system (ANFIS). An ANFIS consists of a supervised learning process that uses data for training and checking (learning dataset), as well as 
for evaluation of the generalization capacity of the model (testing dataset). For this study, from a database composed of 107 cases, $60 \%$ (63 cases) was used for training and approximately $20 \%$ (22 cases) for checking. The remaining $20 \%$ was used for generalization tests.

The consequents $\left(Z_{i}\right)$ in $S_{2}$ were computed as a linear function $\left(f_{i}\right)$ of the input variables $\left(R_{p}, R_{E} I_{5}\right)$, according to:

$$
\begin{aligned}
& \text { IF } R_{p} \text { is } A_{i} \text { AND } R_{E} \text { is } B_{i} \text { AND } I_{5} \text { is } C_{i} \\
& \text { THEN } z_{i}=f_{i}\left(R_{p}, R_{E}, I_{5}\right)=p_{i} R_{p}+q_{i} R_{E}+r_{i} I_{5}+S_{i},
\end{aligned}
$$

where $p_{i}, q_{i}, r_{i}$ and $s_{i}$ are the consequent parameters of the rules in $S_{3}$.

The adjustment of the antecedent parameters is performed in layer $1\left(O_{i}^{1}\right)$ of a total of 5 layers that compose the architecture of the ANFIS:

$$
O_{i}{ }^{1}=\mu_{\mathrm{A} i}(x)
$$

in which $O_{i}^{1}$ measures the membership of the input $x$ in the linguistic value $A_{i}$.

The activation weight $\left(w_{i}\right)$ of each rule is calculated in layer $2\left(\mathrm{O}_{i}^{2}\right)$, given by:

$$
w_{i}=\mu_{\mathrm{A} i}\left(R_{p}\right) \cdot \mu_{\mathrm{B} i}\left(R_{E}\right) \cdot \mu_{\mathrm{C} i}\left(I_{5}\right) .
$$

The activation weight is standardized $\left(\bar{w}_{i}\right)$ in layer $3\left(O_{i}^{3}\right)$, by means of the equation:

$$
\bar{w}_{i}=w_{i} /\left(w_{1}, w_{2}, w_{3}\right)
$$

In layer $4\left(O_{i}^{4}\right)$, the consequent of each rule is computed by:

$$
O_{i}^{4}=\bar{w}_{i} f_{i}\left(R_{p}, R_{E}, I_{5}\right)=\bar{w}_{i}\left(p_{i} R_{p}+q_{i} R_{E}+r_{i} I_{5}+S_{i}\right)
$$

Finally, in layer $5\left(O_{i}^{5}\right)$, the output of the system is obtained by the sum of the signals generated in the previous layer:

$$
O_{i}^{5}=\Sigma_{i} \bar{w}_{i} \cdot f_{i}\left(R_{p}, R_{E}, I_{5}\right)=\Sigma_{i} w_{i} \cdot f_{i} / \Sigma_{i} w_{i} .
$$

Thus, from the learning dataset, operations are performed using the backpropagation algorithm and the least squares method, which provide adjustment of the parameters in the model. During the learning (training and checking), different topologies of the neuro-fuzzy network were evaluated by the subtractive clustering method, with determination of the root-meansquare error (RMSE) and the global accuracy $\left(\theta_{1}\right)$ :

$$
\mathrm{RMSE}=\sqrt{\frac{1}{n} \sum_{i=1}^{n}\left(R_{i}-R_{i}^{\prime}\right)^{2}},
$$

where $n$ is the number of cases and $\bar{R}_{i}$ and $R_{i}$ are, respectively, the risk class assessed by the expert and the one computed by the neuro-fuzzy model for the case $i$, and

$$
\theta_{1}=\frac{1}{n} \sum_{i=1}^{n_{c}} T P_{i},(18)
$$

where $n_{c}$ is the risk class number and $T P_{i}$ is the true positive rate (the number of cases belonging to risk class $i$ correctly classified as such).

To achieve the best model configuration, the RMSE was used as a stopping criterion during the training process. This criterion was selected because it allowed the training process to be stopped at the moment when the error in the checking dataset started to grow suddenly. In this way, it was possible to prevent the undesirable effect of overfitting of the model to the learning dataset, which would lead to loss of generalization capacity during the tests. In turn, the accuracy $\left(\theta_{1}\right)$ was used to select the neuro-fuzzy topology with the best performance during the checking. The generalization capacity of the selected topology was then evaluated using the test samples, based on the accuracy and the kappa index $(k)$ :

$$
k=\left(\theta_{1}-\theta_{2}\right) /\left(1-\theta_{2}\right),(19)
$$

where

$$
\theta_{2}=\frac{1}{n^{2}} \sum_{i=1}^{n_{c}}\left(V_{i} . I_{i}\right),(20)
$$

$V_{i}$ is the number of cases belonging to risk class $i$ according to the expert, and $I_{i}$ is the number of cases classified by the model as belonging to the same class.

The agreement between the risk class attributed by the expert and that calculated by the model during the tests was considered as a slight agreement for $k$ $\boldsymbol{\epsilon}$ [0 0.2[, fair agreement for $k \in[0.20 .4$ [, moderate agreement for $k \in[0.40 .6$ [, substantial agreement for $k \in[0.60 .8$ [, and almost perfect agreement for $k \in[0.8$ 1], according to the classification of Landis and Koch (1977).

Revista Árvore. 2018;42(1):e420106 


\section{RESULTS}

\subsection{Decision support system for the integrated analysis of risk}

Firstly, for each indicator $\left(I_{i}\right)$, a set of analysis criteria was selected $\left(c_{i j}\right)$ and then weighted by the AHP method. The indicators and analysis criteria resulting from this process are presented in Table 1.

Considering the prioritized variables and their respective scales of risk assessment, the first and second fuzzy systems $S_{1}$ and $S_{2}$ were constructed to model the indices $R_{p}$ and $R_{E}$, resulting in the architecture shown in Figure 1 .

As can be seen in Figure 1, the risk level of each indicator was categorized as minimum $(M)$, slightly worrying $(S W)$, worrying $(W)$, very worrying $(V W)$, and extreme $(E)$. From that, the rule base was then constructed using conditional statements, such as:

IF $I_{1}$ is 'minimum $(M)$ ' AND $I_{2}$ is 'worrying $(W)$ '

THEN $R_{p}$ is 'slightly worrying $(S W)$ '.

The global index of risk $\left(R_{G}\right)$ was modeled by the third fuzzy system $\left(S_{3}\right)$, which linked the outputs of $S_{1}$ and $S_{2}$ to the indicator of potential targets $\left(I_{5}\right)$. The results of the evaluation of different neuro-fuzzy topologies in $S_{3}$ are presented in Table 2 .

In the checking step, the topology with cluster radius 0.6 was the one with the greatest accuracy and was therefore selected for the generalization tests performed during the case study (Figure 2), presented below.

\subsection{Case study to evaluate the generalization capacity of the model}

As a result of the visual tree assessment, several cases of risk due to inappropriate management practices were observed. Among the most frequent cases were the stumps left after pruning and the unsatisfactory occupation of the surrounding area. The stumps led to a chain of consequences detrimental to the phytosanitary state of the tree, with hindered occlusion of cuts, induction of shoots and epicormic branches, necrosis, deterioration, and loss of vitality. Frequent factors associated with environmental conditions were mainly related to soil sealing and surrounding buildings, which hampered the development of roots, stem, and crown, hence compromising the stability of the tree.

(a)
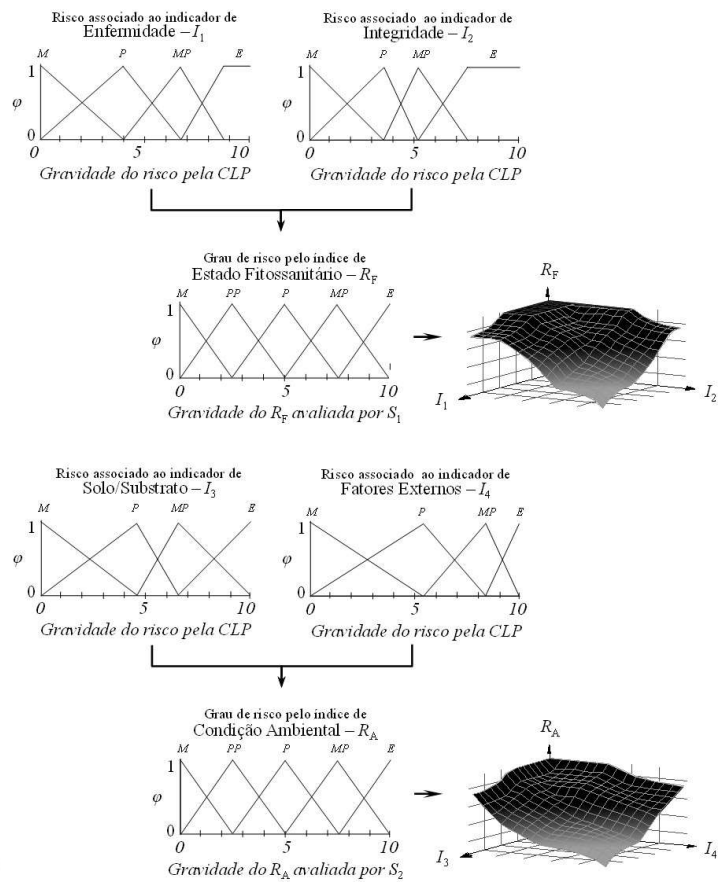

Figure 1 - Fuzzy modeling of $R_{\mathrm{p}}$ (a) and $R_{\mathrm{E}}(\mathrm{b})$ in the risk classes: minimum $(M)$, slightly worrying $(S W)$, worrying $(W)$, very worrying $(V W)$, and extreme $(E)$.

Figura 1 - Modelagem fuzzy de RP (a) e RE (b) nas classes de risco: mínimo $(M)$, pouco preocupante $(S W)$, preocupante $(W)$, muito preocupante $(V W) e$ extremamente preocupante $(E)$.

Table 1 - Weighting of risk analysis criteria in urban afforestation.

Tabela 1 - Ponderação dos critérios de análise de risco na gestão da arborização urbana.

\begin{tabular}{|c|c|c|c|c|c|c|c|c|c|c|c|c|}
\hline & & \multicolumn{10}{|c|}{ Influence range in the subtractive clustering } & \multirow[b]{2}{*}{0.70} \\
\hline & & 0.20 & 0.25 & 0.30 & 0.35 & 0.40 & 0.45 & 0.50 & 0.55 & 0.60 & 0.65 & \\
\hline \multirow[b]{2}{*}{ Training } & RMSE & 0.00 & 0.00 & 0.00 & 0.07 & 0.01 & 0.01 & 0.01 & 0.01 & 0.01 & 0.09 & 0.15 \\
\hline & $\theta(\%)$ & 100 & 100 & 100 & 100 & 100 & 100 & 100 & 100 & 100 & 100 & 100 \\
\hline \multirow{2}{*}{ Checking } & RMSE & 0.34 & 0.16 & 0.93 & 0.36 & 0.38 & 0.71 & 0.74 & 0.76 & 0.24 & 0.43 & 0.50 \\
\hline & $\theta_{1}(\%)$ & 81.8 & 81.8 & 90.9 & 90.9 & 81.8 & 81.8 & 86.4 & 81.8 & 95.5 & 77.3 & 68.2 \\
\hline
\end{tabular}


Table 2 - Performance of the neuro-fuzzy topologies during the machine learning in $S_{3}$.

Tabela 2 - Desempenho de topologias da rede neuro-fuzzy durante o aprendizado de máquina em $S_{3}$.

\begin{tabular}{|c|c|c|c|c|c|}
\hline Index & Indicator & Analysis criterion $\left(C_{i j}\right)$ & Value $\left(C_{i j}\right)$ & Weight $\left(W_{i j}\right)$ & $\begin{array}{l}\text { Cumulative weight } \\
\text { by indicator }\left(I_{i}\right)\end{array}$ \\
\hline \multirow{9}{*}{$R_{\mathrm{P}}$} & \multirow{5}{*}{$I_{1}$} & chancre $\left(c_{11}\right)$ & $0-10$ & 0.396 & 3.96 \\
\hline & & fungus $\left(c_{12}\right)$ & $0-10$ & 0.272 & 6.68 \\
\hline & & $\operatorname{gall}\left(c_{13}\right)$ & $0-10$ & 0.208 & 8.76 \\
\hline & & parasitic plant $\left(c_{14}\right)$ & $0-10$ & 0.124 & 10 \\
\hline & & senility / instability $\left(c_{21}\right)$ & $0-10$ & 0.361 & 3.61 \\
\hline & \multirow{4}{*}{$I_{2}$} & injuries / fractures / cavities $\left(c_{22}\right)$ & $0-10$ & 0.159 & 5.2 \\
\hline & & structural necrosis $\left(c_{23}\right)$ & $0-10$ & 0.237 & 7.57 \\
\hline & & epicormic branch $\left(c_{24}\right)$ & $0-10$ & 0.129 & 8.86 \\
\hline & & included bark $\left(c_{25}\right)$ & $0-10$ & 0.114 & 10 \\
\hline \multirow{9}{*}{$R_{\mathrm{P}}$} & \multirow{3}{*}{$I_{3}$} & soil depth / volume $\left(c_{31}\right)$ & $0-10$ & 0.454 & 4.54 \\
\hline & & exposed root / grounded stem base $\left(c_{32}\right)$ & $0-10$ & 0.199 & 6.53 \\
\hline & & waterproofing / compaction $\left(c_{33}\right)$ & $0-10$ & 0.347 & 10 \\
\hline & \multirow{3}{*}{$I_{4}$} & location / surroundings $\left(c_{41}\right)$ & $0-10$ & 0.539 & 5.39 \\
\hline & & wind / rain $\left(c_{42}\right)$ & $0-10$ & 0.297 & 8.36 \\
\hline & & slope of the terrain $\left(c_{43}\right)$ & $0-10$ & 0.164 & 10 \\
\hline & \multirow{3}{*}{$I_{5}$} & people / animals $\left(c_{51}\right)$ & $0-10$ & 0.723 & 7.23 \\
\hline & & vehicles (movable property) $\left(c_{52}\right)$ & $0-10$ & 0.103 & 8.26 \\
\hline & & buildings (real estate) $\left(c_{53}\right)$ & $0-10$ & 0.174 & 10 \\
\hline
\end{tabular}

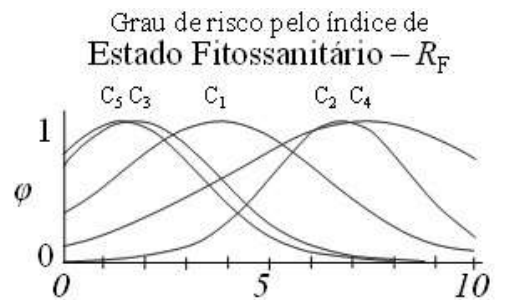

Gravidade do $R_{\mathrm{F}}$ avaliada por $S_{1}$

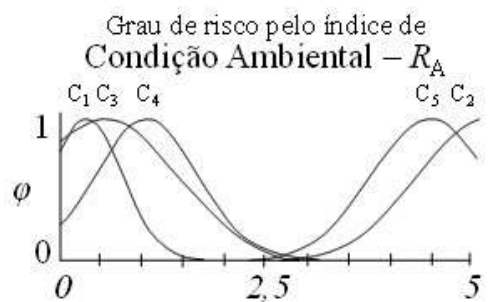

Gravidade do $R_{\mathrm{A}}$ avaliada por $\mathrm{S}_{2}$

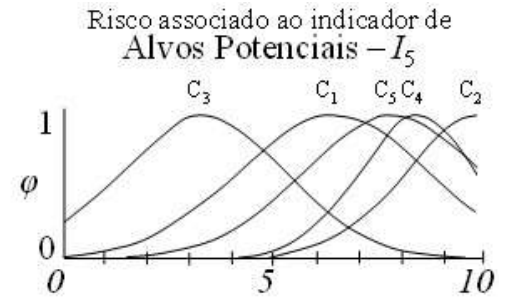

Gravidade do risco pela CLP

$$
\begin{array}{ll}
\text { Se } R_{\mathrm{F}} \dot{e} C_{1} \text { e } R_{\mathrm{A}} \dot{e} C_{1} \text { e } I_{5} \dot{e} C_{1} \text { Então } R_{\mathrm{G}} \dot{e} A & \rightarrow f_{1}=-0,82 R_{\mathrm{F}}+12,52 R_{\mathrm{A}}-1,74 I_{5}+0.30 \\
\operatorname{Se} R_{\mathrm{F}} \dot{e} C_{2} \text { e } R_{\mathrm{A}} \dot{e} C_{2} \text { e } I_{5} \dot{e} C_{2} \text { Então } R_{\mathrm{G}} \dot{e} M & \rightarrow f_{2}=-0,03 R_{\mathrm{F}}+0,002 R_{\mathrm{A}}-0,02 I_{5}+5,36 \\
\operatorname{Se} R_{\mathrm{F}} \dot{e} C_{3} \text { e } R_{\mathrm{A}} \dot{e} C_{3} \text { e } I_{5} \dot{e} C_{3} \text { Então } R_{\mathrm{G}} \dot{e} M D & \rightarrow f_{3}=-0,05 R_{\mathrm{F}}+0,90 R_{\mathrm{A}}-0,04 I_{5}+0.29 \\
\operatorname{Se} R_{\mathrm{F}} \dot{e} C_{4} \text { e } R_{\mathrm{A}} \dot{e} C_{4} \text { e } I_{5} \dot{e} C_{4} \text { Então } R_{\mathrm{G}} \dot{e} P & \rightarrow f_{4}=-0,05 R_{\mathrm{F}}+3,61 R_{\mathrm{A}}+0,02 I_{5}-0,92 \\
\operatorname{Se} R_{\mathrm{F}} \dot{e} C_{5} \text { e } R_{\mathrm{A}} \dot{e} C_{5} \text { e } I_{5} \dot{e} C_{5} \text { Então } R_{\mathrm{G}} \dot{e} M P & \rightarrow f_{5}=-0,02 R_{\mathrm{F}}+0,004 R_{\mathrm{A}}-0,01 I_{5}+4,11
\end{array}
$$
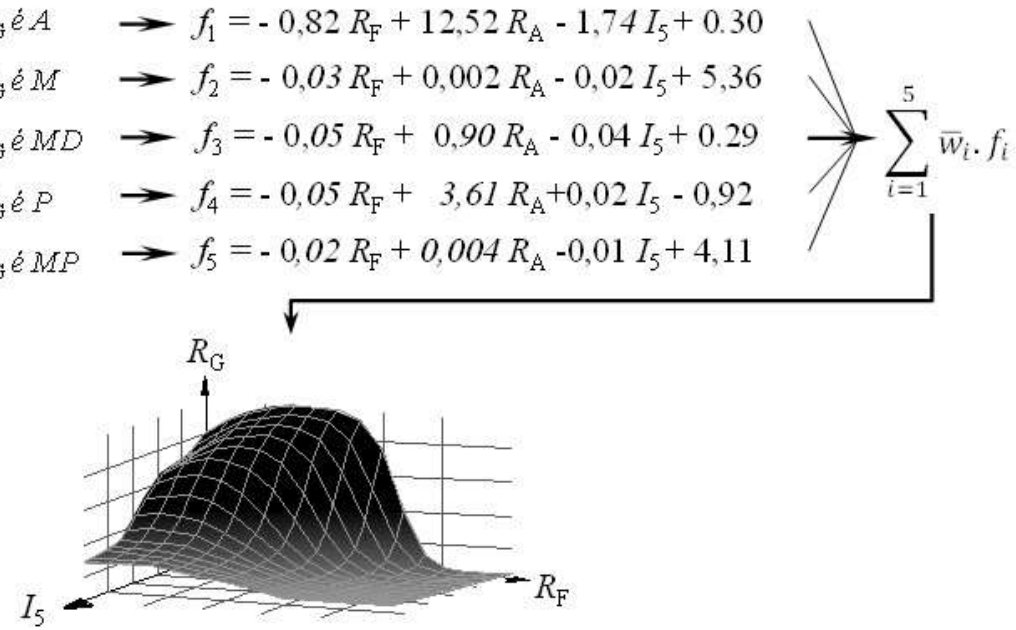

Figure 2 - Neuro-fuzzy modeling of $R_{\mathrm{G}}$ in the risk classes: absent $(A)$, minimum $(M)$, moderate $(M O)$, worrying $(W)$, and very worrying $(V W)$.

Figura 2-Modelagem neuro-fuzzy de RG nas classes de risco: ausente (A), mínimo (M), moderado (MO), preocupante $(W)$ e muito preocupante $(V W)$.

Revista Árvore. 2018;42(1):e420106 
In order to demonstrate how the index value is obtained by fuzzy modeling, an example is provided for a tree individual belonging to the species Nectandra megapotamica. The evaluation of this arboreal individual revealed the occurrence of drastic pruning, necrosis in the stem, epicormic branches, mechanical injuries, inclined trunk, and presence of fungi. The overall values obtained for the indicators of disease $\left(I_{1}\right)$ and structural integrity $\left(I_{2}\right)$ were 2.72 and 8.86 , respectively. From the integrated analysis of $I_{1}$ and $I_{2}$, the first fuzzy system $\left(S_{1}\right)$ provided a risk index associated with phytosanitary status $\left(R_{\mathrm{p}}\right)$ equal to 8.73 (Figure $3 \mathrm{a}$ ).

In the same evaluation, no influence was observed for factors related to the root or stem base, or for soil waterproofing or compaction. However, being located in an open field, the tree under analysis was subject to high exposure to intense wind and rain, which could cause the breaking or fall of devitalized branches. The overall values for the indicators associated with soil conditions $\left(I_{3}\right)$ and the influence of external factors $\left(I_{4}\right)$ were 0 and 2.97, respectively, from which the second system $\left(S_{2}\right)$ provided an index of risk associated with environmental conditions $\left(R_{\mathrm{E}}\right)$ equal to 1.71 (Figure $3 \mathrm{~b}$ ).

For the same case, the indicator associated with the presence of potential targets $\left(I_{5}\right)$ totaled 8.26. The integrated analysis of $R_{\mathrm{p}}, R_{\mathrm{E}}$, and $I_{5}$ by means of $S_{3}$ then resulted in a global risk index $\left(R_{\mathrm{G}}\right)$ of 4.99 , which was equivalent to the same risk class (very worrying) attributed by the expert (Figure 3c).

For the other arboreal individuals evaluated in the present study, the integrated analysis of the risk indicators followed the same fuzzy inference process described for the featured case.

From the total of 107 cases, only in 2 cases $(1.6 \%)$ was the tree classified as presenting no risk (class 1), while 10 cases $(7.9 \%)$ showed minimum risk (class 2$)$, $12(9.4 \%)$ showed moderate risk (class 3), 41 (32.3\%) showed worrying risk (class 4 ), and 42 (33.1\%) showed very worrying risk (class 5 ). It should be noted that in evaluation of the neuro-fuzzy model, the learning (training and checking) and testing datasets were randomly constructed, but with the same proportions of cases in these different risk classes.

\section{DISCUSSION}

In order to obtain a global risk index $\left(R_{\mathrm{G}}\right)$, the proposed model performs a multicriteria analysis of all the parameters evaluated. In this process, a score from 0 to 10 is initially assigned for each criterion, according to the visual evaluation. The value of each indicator $\left(I_{i}\right)$ is then obtained by means of a weighted linear combination (WLC), given by:

$$
I_{i}=c_{i 1} w_{i 1}+c_{i 2} w_{i 2}+\ldots+c_{i n} w_{i n}, j=(1,2, \ldots, n),
$$

where $c_{i j}$ is the value given in the visual tree assessment (VTA) by the specialist, and $w_{i j}$ is the priority weight of the criterion defined by means of the AHP method (see Table 1).

Following the evaluation process, the index values are calculated by the fuzzy and neuro-fuzzy inference systems. The indexes $R_{\mathrm{P}}$ and $R_{\mathrm{E}}$ are computed using $S_{1}$ and $S_{2}$, respectively (see Figure 3 ). The $S_{3}$ system then integrates the values previously calculated for the indicator $I_{5}$ and the indexes $R_{\mathrm{P}}$ and $R_{\mathrm{E}}$, resulting in the final index $\left(R_{\mathrm{G}}\right)$ with risk class values ranging from 1 to 5 . It should be noted that the proposed values for assessing each parameter $\left(c_{i j}\right)$ are not fixed, allowing a variation from 0 to 10 , as necessary for case-by-case analysis.

Four classes of linguistic values were proposed to express the severity of the risk associated with each indicator (see Figure 1). The first class corresponds to the minimum $(M)$ risk, with maximum membership close to zero (the value generated by the WLC), reflecting cases in which no risk factor is observed. The second and third classes reflect worrying $(W)$ and very worrying $(V W)$ risk, respectively, with maximum membership around the first and second accumulated values in the risk severity scale (see the last column of Table 1), respectively. Finally, the fourth class reflects extreme $(E)$ risk, with maximum membership for the third accumulated value in the scale. Consequently, the proposed model considers the occurrence of a single criterion with serious risk factor to classify the situation as 'worrying', the occurrence of two factors to reflect 'very worrying' risk, and from 3 risk factors to classify the case as 'extreme risk'. Intermediate values express transition between the risk classes.

The results presented in Table 2 demonstrate that the neuro-fuzzy model provided high performance during the training. Even for a limited database with only 107 cases, the model achieved fits capable of calculating the same class of risk given by the expert in the visual tree assessment. 


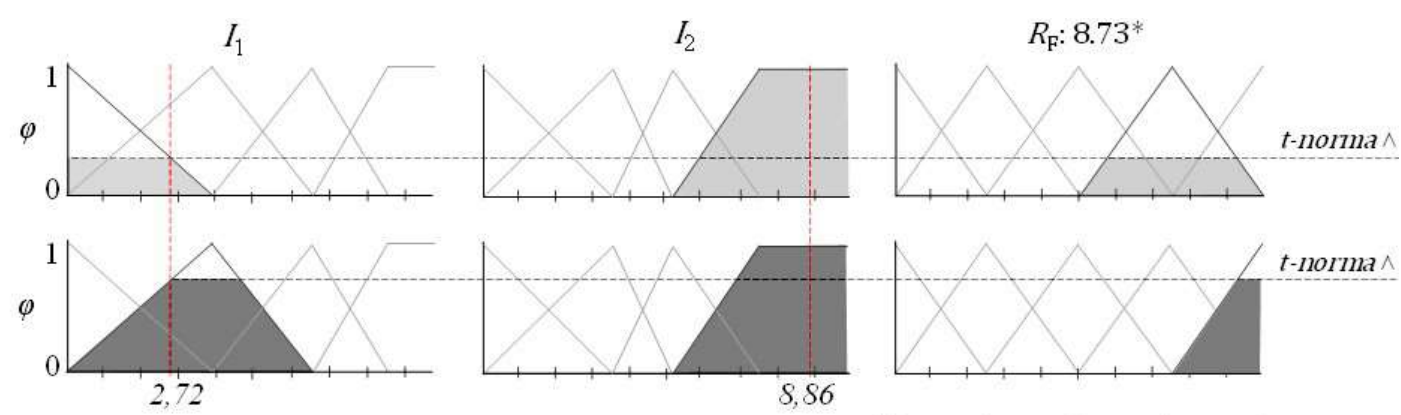

(a) * Valor padronizado após a defizificação

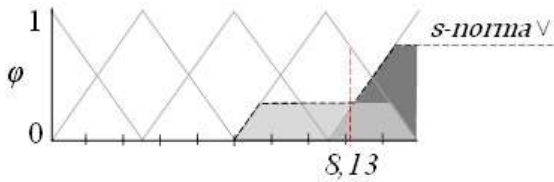

Gravidade avaliada por $S_{1}$
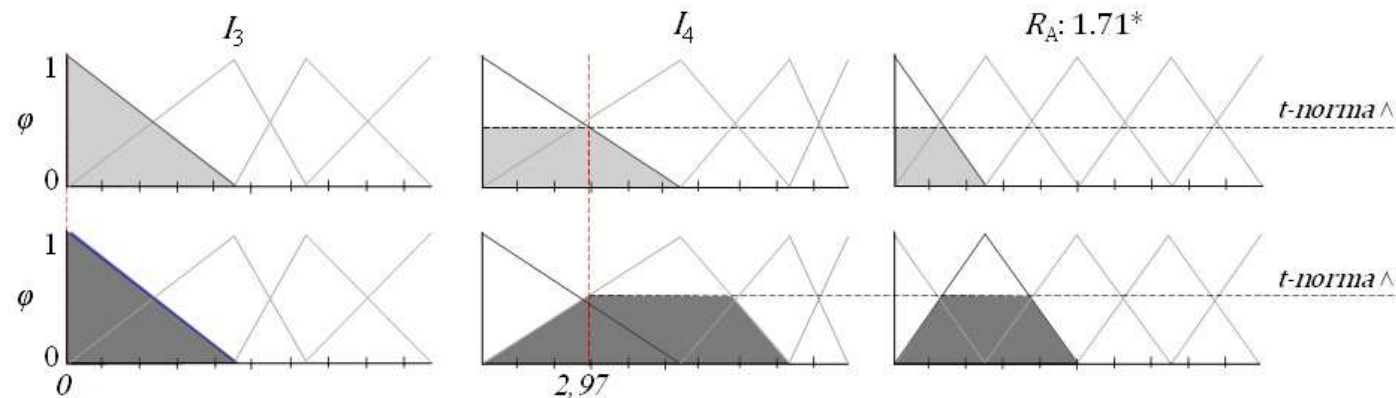

(b) * Valor padronizado após a defuzificação
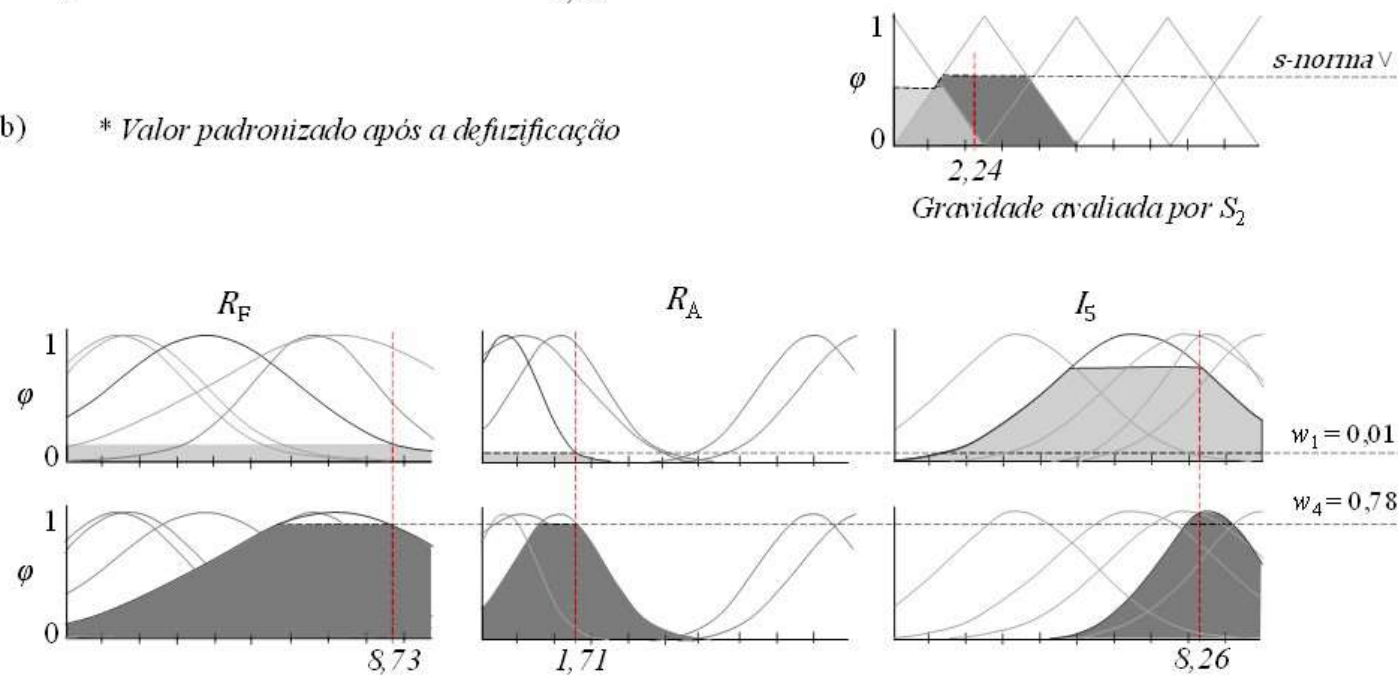

$4=0,78$

$$
\begin{aligned}
& f_{1}=-0,82 \cdot(8,73)+12,52 \cdot(1,71)-1,74 \cdot(8,26)+0.30=0,28, \bar{w}_{1}=(0,01 /(0,01+0,78))=0,01 \\
& f_{4}=-0,05 \cdot(8,73)+3,61 \cdot(1,71)+0,02 \cdot(8,26)-0,92=5,05, \bar{w}_{4}=(0,81 /(0,01+0,78))=0,99
\end{aligned}
$$

(c) $R_{G}=\bar{w}_{1} \cdot f_{1}+\bar{w}_{4} \cdot f_{4}=0,28 \cdot(0,01)+5,05 \cdot(0,99)=4,99 \rightarrow$ classe de risco: muito preocupante

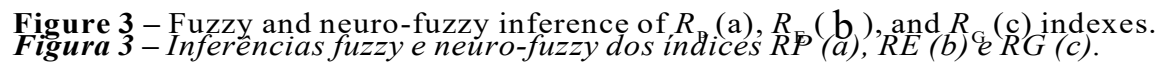

Revista Árvore. 2018;42(1):e420106 
It can be seen from Figure 2 that ANFIS operates based on the formation of clusters $\left(C_{\mathrm{j}}\right)$, computing the global risk index $\left(R_{\mathrm{G}}\right)$ as a linear combination of input variables $\left(R_{\mathrm{P}}, R_{\mathrm{E}}\right.$, and $\left.I_{5}\right)$. As a result, the topology with best performance provided an accuracy of $95.5 \%$ during the check. Considering the cases correctly classified during training, the model achieved $98.8 \%$ accuracy in the learning stage.

As shown in parts (a) and (b) of Figure 3, the fuzzy relational composition acts so that the minimal operator $(\wedge)$ assigns the least membership in the input variables to the consequent class. In turn, the consequents of each activated rule are aggregated by the maximum operator $(\mathrm{v})$. Finally, the index values $\left(R_{\mathrm{P}}\right.$ and $\left.R_{\mathrm{E}}\right)$ are computed by standardizing the defuzzified value, given by the center of gravity of the area formed in the union of the consequents.

Despite the smaller numbers of cases in the lowest risk classes $(1,2$, and 3$)$, during the tests the model maintained the hit rate obtained at the checking stage, attributing the same risk class given by the expert in 21 of the 22 cases evaluated, including the correct classification of the only case of no risk (class 1).

During the learning process, there was only one omission error in the checking subset, where a case of risk class 3 was mistakenly assigned to class 4 , resulting in a commission error in the latter. During the test, there was also a single omission, in class 5 , of a case that was erroneously classified as class 4 , hence accruing two commission errors. Taking into account the number of cases in each class, the omission error rates were $33.3 \%$ in class 3 during the check, and $11.1 \%$ for class 5 in the tests. The commission errors were $10 \%$ and $11.1 \%$, both in class 4 , during the checking and testing, respectively. Despite a more significant error rate during the check, error rates were low during the tests. The kappa index value was 0.95 , indicating an almost perfect agreement between the neuro-fuzzy model and the expert's evaluation.

An important consideration is that it is possible to add or remove parameters, refine the weighting values, and use new databases, making the model adaptable to the conditions and criteria of the user, as required by a particular application. In addition, the progressive increase of the number of cases in the database allows the recognition of new patterns, providing a continuous improvement in model performance. Therefore, these aspects constitute possibilities for further advances in future studies.

\section{CONCLUSION}

Using a database, consultation with experts, and information from the literature, a neuro-fuzzy-based model was developed for multi-criteria analysis of 18 parameters integrated using 3 indexes and 5 indicators of risk, applied to the management of urban afforestation. Satisfactory performance was achieved for application of the model in a case study. The neuro-fuzzy model presented accuracies of $98.8 \%$ in learning and $95.5 \%$ in generalization tests, and was in almost perfect agreement $(k>0.8)$ with visual tree assessment by an expert. Therefore, the findings show that neuro-fuzzy modeling is a promising alternative for risk analysis in urban afforestation management, using computational intelligence.

\section{REFERENCES}

Baumgarten H. A administração das áreas verdes públicas e espaços livres nas cidades alemãs. Rev. Soc. Bras. Arb. Urb. 2006;1(1):90-8.

Bressane A, Biagolini CH, Mochizuki PS, Roveda JAF, Lourenco RW. Fuzzy-based methodological proposal for participatory diagnosis in the linear parks management. Ecol Indic. 2017;80:153-62. http://dx.doi.org/10.1016/j.ecolind.2017.05.023.

Bryant MM. Urban landscape conservation and the role of ecological greenways at local and metropolitan scales. Landsc Urban Plan. 2006;76(1-4):23-44. http://dx.doi.org/10.1016/ j.landurbplan.2004.09.029.

Galenieks A. Importance of urban street tree policies: a comparison of neighbouring Southern California cities. Urban For Urban Green. 2017;22:105-10. http://dx.doi.org/10.1016/ j.ufug.2017.02.004.

Godbey GC, Caldwell LL, Floyd M, Payne LL. Contributions of leisure studies and recreation and park management research to the active living agenda. Am J Prev Med. 2005;28(2 Suppl):150-8. http://dx.doi.org/10.1016/j.amepre.2004.10.027. PMid:15694523.

Gonçalves W, Stringheta ACO, Coelho LL. Análise de árvores urbanas para fins de supressão. Rev. Soc. Bras. Arb. Urb. 2007;2(4):1-19.

Jang JSR. ANFIS: adaptive-network-based fuzzy inference systems. IEEE Trans Syst Man Cybern. 
1993;23(3):665-85. http://dx.doi.org/10.1109/ 21.256541 .

Janssen JAEB, Krol MS, Schielen RMJ, Hoekstra AY, de Kok J-L. Assessment of uncertainties in expert knowledge, illustrated in fuzzy rule-based models. Ecol Modell. 2010;221(9):1245-51. http:// dx.doi.org/10.1016/j.ecolmodel.2010.01.011.

Landis JR, Koch GG. The measurement of observer agreement for categorical data. Biometrics. 1977;33(1):159-74. http://dx.doi.org/ 10.2307/2529310. PMid:843571.

Mamdani EH, Assilian S. An experiment in linguistic synthesis with a fuzzy logic controller. Int J Man Mach Stud. 1975;7(1):1-13. http:// dx.doi.org/10.1016/S0020-7373(75)80002-2.

Martins LFV, Andrade HHB, Angelis BLD. Relação entre podas e aspectos fitossanitários em árvores urbanas na cidade de Luiziana, Paraná. Rev. Soc. Bras. Arb. Urb. 2010;5(4):141-55.

Mattheck C, Breloer H. Field guide for visual tree assessment (VTA). J Arboric. 1994;18(1):1-23. http://dx.doi.org/10.1080/03071375.1994.9746995.
Mattheck C, Breloer $\mathrm{H}$. The body language of trees: a handbook for failure analysis. London: Her Majesty's Stationery Office; 1997.

Morelli F, Lima MG, Sousa WC Jr. Influência do ambiente natural sobre o ambiente construído: um estudo sobre o índice de chuva dirigida.

Ambiente Soc. 2012;15(1):41-52. http://dx.doi.org/ 10.1590/S1414-753X2012000100004.

Saaty TL. Decision making with the analytic hierarchy process. Int J Serv Sci. 2008;1(1):83-98. http://dx.doi.org/10.1504/IJSSCI.2008.017590.

Sampaio ACF, Duarte FG, Silva EGC, Angelis BLD, Blum CT. Avaliação de árvores de risco na arborização de vias públicas de Nova Olímpia, Paraná. Rev. Soc. Bras. Arb. Urb. 2010;5(2):82-104.

Santos NRZ, Teixeira IF. Arborização de vias públicas: ambiente x vegetação. Porto Alegre: Instituto Souza Cruz; 2001.

Volpe-Filik A, Silva LF, Lima AMLP. Avaliação da arborização de ruas do bairro São Dimas na cidade de Piracicaba/SP através de parâmetros qualitativos Rev. Soc. Bras. Arb. Urb. 2007;2(1):1-10. 